日本臨床麻酔学会第 38 回大会シンポジウム 日臨麻会誌 Vol.40 No.1, $44 \sim 49,2020$

区域麻酔と予後

区域麻酔はハイリスク患者の予後に影響するか？

村田寬明*

[要旨］2000年代初頭までに報告されたメ夕解析などの各種報告では, 硬膜外麻酔や脊䯣くも膜 下麻酔は周術期合併症や死亡率を減少させ, 予後改善に寄与しうるとされてきた. しかしその後の 報告では, 硬膜外麻酔により周術期合併症や死亡率は減少しないという結論の報告も増加してきた. 周術期全身管理法の進歩や内視鏡下手術の普及などにより硬膜外麻酔の利点が減少してきたことが 理由として考えられる. しかし, 区域麻酔の有用性が完全に否定されたわけではなく, 近年ではビ ッグデータを二次利用することで麻酔法が患者の予後に及ぼす影響についての解析が行われてい る. 本稿では, 区域麻酔がハイリスク患者の術後経過に与える影響について, 病態や術式ごとに分 類し文献的に考察する.

キーワード : 区域麻酔, 予後, ハイリスク患者

\section{はじめに}

区域麻酔はハイリスク患者の術後経過に影響を与 えるのであろうか. 少し古い報告では，全身麻酔に 硬膜外麻酔を併用すると全身麻酔単独と比較して死 亡率が低下するとされてきた ${ }^{11}$.しかし，近年のメ 夕解析では，全身麻酔に硬膜外麻酔をはじめとする 区域麻酔を併用することは，周術期死亡率の低下や 呼吸・循環器系合併症発生率の低下にほとんど影響 しないとされている ${ }^{2)}$ むむし硬膜外麻酔による鎮 痛効果が十分に得られない可能性や, 頻度は低いな がらも生じうる重篤な合併症を考慮すると, 硬膜外 麻酔の使用については個々の症例でリスク/ベネフ イットを十分に検討する必要がある。各種手術を受 けるハイリスク患者に対し，麻酔法が予後に与える 影響を調査した報告が散見される。これらに加えて
近年は，システマティックレビューやメ夕解析，ビ ッグデータの二次利用による調査検討が増加傾向に ある。また，超音波ガイド下神経ブロックの普及に 伴い，区域麻酔の中でも硬膜外麻酔や脊髄くも膜下 麻酔だけでなく末梢神経ブロックを対象とした研究 もある。本稿では，麻酔法がハイリスク患者の術後 経過に与える影響について，区域麻酔と全身麻酔の 比較あるいは全身麻酔単独と区域麻酔併用全身麻酔 の比較という視点を中心に文献的に考察する。

\section{I 心血管疾患合併ハイリスク患者の非心臓手術}

心血管疾患合併ハイリスク患者の非心臓手術にお いて区域麻酔が術後経過に与える影響は, POISE trial $^{3)}$ おび゙POISE-2 trial $^{4)}$ のデー夕を二次利用し て調査された ${ }^{5)}$. 6). POISE trial は，非心臟手術を受 ける動脈硬化疾患患者 8,351 症例(冠動脈疾患 43\%, 
末梢血管疾患 $41 \%$, 脳卒中 $15 \%)$ を対象に， $\beta$ ブロ ッカーであるメトプロロール投与群とプラセボ投与 群を比較した無作為化比較対照試験である ${ }^{3)}$. 主要 評価項目 (心血管死 - 非致死的心筋梗塞 - 非致死的 心停止)および心筋梗塞はメトプロロール群で有意 に少なかった。しかし, 死亡と脳卒中はメトプロロ ール群で有意に多かった。このPOISE trialのデー 夕を二次利用し, 主要評価項目 (心血管死・非致死 的心筋梗塞 - 非致死的心停止) と春髄幹麻酔 (脊髄く も膜下麻酔/ 硬膜外麻酔) 実施の有無との関連を調 查したところ, 脊髄幹麻酔を実施した群では全身麻 酔単独群と比較して主要評価項目 (心血管死・非致 死的心筋梗塞・非致死的心停止)が有意に多かった。 また，サブグルーブ解析の結果，胸部硬膜外麻酔と 全身麻酔を併用した患者群では全身麻酔単独群と比 較して主要評価項目 (心血管死・非致死的心筋梗塞 非致死的心停止) に加え血圧低下も有意に多かっ た ${ }^{5)}$.

POISE-2 trial は, 非心臓手術を受ける血管系合 併症の高リスク患者 10,010 症例を対象にアスピリン 投与群 $(4,382$ 症例 $)$ とプラセボ投与群 $(5,628$ 症例 $)$ を 比較した無作為化比較対照試験である ${ }^{4)}$. 主要評価 項目である介入後 30 日時点での死亡と心筋梗塞は 両群に有意差を認めず, 大出血はアスピリン投与群 で有意に多かった。このPOISE-2 trialのデータを 二次利用し, 術中の脊髄幹麻酔あるいは術後の硬膜 外鎮痛実施の有無と, 介入後 30 日時点での死亡や 非致死的心筋梗塞などの有害事象との関連を調査し たところ, 術中の春髄幹麻酔および術後の硬膜外鎮 痛は介入後 30 日時点での死亡および非致死的心筋 梗塞, 脳卒中発生率との関連はなかった。臨床的に 意義のある血圧低下 (収縮期血圧 $<90 \mathrm{mmHg}$ ) は, 術中の春髄幹麻酔実施群は非実施群より有意に少な く, 術後硬膜外鎮痛実施群は非実施群との有意差を 認めなかった ${ }^{6)}$.

POISE trialおよびPOISE-2 trialを二次利用して 得られたデータは，区域麻酔が心血管疾患合併八イ
リスク患者の非心臓手術の術後経過に与える影響に ついて一定の傾向を示しておらず，これらの解析結 果を臨床現場にフィードバックする際は慎重な対応 が必要である。

\section{II 腹部大動脈瘤手術}

典型的には腹部大動脈の直径が $3 \mathrm{~cm}$ 以上になつ たものが腹部大動脈瘤と定義されている，原因は多 因子からなるが動脈硬化が関係している場合が多く, 腹部大動脈瘤患者では 25〜 55\%の症例で動脈硬化 が併存すると言われている7). また，半数以上の症 例で中等度以上の冠動脈疾患を有することや ${ }^{8), 9)}$, 慢性腎臓病患者は腹部大動脈瘤を併発しやすいこと が明らかにされており ${ }^{10)}$ ，腹部大動脈瘤患者は心血 管系疾患を合併しやすいことが示唆される．腹部大 動脈瘤の治療法は人工血管置換術または血管内ステ ントグラフト内挿術であり, 何らかの麻酔が必要と なる。

周術期鎮痛法として硬膜外鎮痛法とオピオイド主 体の鎮痛法が腹部大動脈瘤手術の予後に与える影響 を比較したコクランシステマティックレビューで は，全身麻酔に硬膜外鎮痛法を併用することの有用 性を示している ${ }^{11)}$. 特にエビデンスレベルの高い項 目として鎮痛効果が高いこと, 消化管出血のリスク が低いことを挙げている。同様にVascular Study Group of New England data registryを用いた後方 視的調査によると, 待機的な腹部大動脈瘤手術に全 身麻酔と硬膜外麻酔を併用すると, (1)術後 5 年生存 率が高かった $(74 \%$ vs 65\%)，(2)腸管虚血が有意に 減少した, (3)呼吸器合併症が有意に減少した, (4)血 液浄化を必要とする割合が有意に減少した，と報告 されている ${ }^{12)}$. 一方で, 創部関連の合併症や心合併 症に有意差は認めなかった。以上より, 待機的腹部 大動脈瘤手術を受ける患者に対する麻酔は適応があ れば全身麻酔に硬膜外麻酔を併用することで予後の 改善につながると考えられる。しかしながら, 術中 のヘパリン使用や出血量増加に伴う凝固異常など硬 
膜外カテーテル留置を躊躇する状況もあるため, 硬 膜外鎮痛法の適応はリスクとべネフィットを十分に 考慮して決定されるべきである。

腹部大動脈瘤に対するステントグラフト内挿術の 麻酔管理法として，区域麻酔で管理した 215 症例と 全身麻酔で管理した 140 症例を比較すると, 周術期 死亡率は区域麻酔群で有意に低いことが明らかにな った。一方で合併症, 在院日数, 再手術, 30 日以内 の再入院に有意差はなかった。また，15論文 15,472 症例のメ夕解析を行ったところ, やはり周術期死亡 率は区域麻酔群で有意に低く，在院日数も区域麻酔 群で有意に短かった ${ }^{13)}$. 腹部大動脈溜に対する予定 のステントグラフト内挿術に対する麻酔管理を行う 場合, 患者の状態など個々の症例で検討は必要であ るが区域麻酔法あるいは局所麻酔法による麻酔管理 は検討するべきかもしれない.

\section{III ハイリスク患者に対する下肢切断術}

糖尿病や閉塞性動脈硬化症などによる下肢血流障 害が原因となる下肢切断術患者の多くは心血管系疾 患をはじめ種々の合併症を有するハイリスク患者で ある.下肢切断術は大腿切断術 (above knee amputation : AKA) と下腿切断術(below knee amputation : BKA) に大別される。過去の報告では30日死 亡率は AKA 患者で $16.5 \%, B K A$ 患者で $5.7 \%$ といず れも高い ${ }^{14)}$. 八イリスク患者に対する下肢切断術の 術後経過と麻酔法の関連性については, The American College of Surgeons National Surgical Quality Improvement Programのデー夕を利用し解析した 大規模研究がある。 日常生活動作 (入浴, 着替え, 食事，トイレ使用)が自立していないなど，何らかの 機能障害を有する 75 歳以上の下肢切断術患者 3,260 症例(AKA 59\%/BKA 41\%)における麻酔法と術 後経過の関連性を調査した結果，麻酔法による術後 合併症に差異は認めなかった ${ }^{15)}$.さらに，より八イ リスク患者の多い集団である AKA 患者のみ 9,999 症例を対象として麻酔法と術後経過の関連性を調査
した結果，やはり麻酔法による術後経過の差異は認 めなかった ${ }^{16)}$. 現時点では, 下肢切断術の予後に麻 酔法の選択が与える影響は大きくないと考えられる が，これらの研究結果は術後鎮痛や幻肢痛に関する 評価は行っていないことに注意が必要である。

\section{IV 大腿骨近位部骨折手術}

大腿骨近位部骨折は典型的な骨粗鬆性骨折であ り，高齢者が転倒して受傷するパターンが多い。大 腿骨近位部骨折は関節内骨折である大腿骨頸部骨折 と関節外骨折である大腿骨転子部骨折に大別され る。2000年に公表された大腿骨近位部骨折患者に 対する麻酔法の影響を調査したランダム化比較試験 15 論文の 2,162 症例を検討したメ夕解析では，大腿 骨近位部骨折手術において全身麻酔に対する区域麻 酔の優位性として，(1)術後30日以内の死亡症例が 有意に少ない, (2)術後深部静脈血栓症の発生率が有

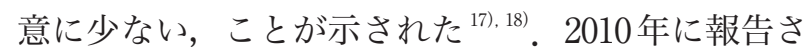
れた 56 論文の 18,715 症例を検討した解析において もこれらを支持する結果が得られた ${ }^{19)}$. しかし，そ の後2016年に公表された再解析結果 $(28$ 論文 2,976 症例)では，区域麻酔の優位性は示されなかった ${ }^{20)}$. しかし, これらのメ夕解析のエビデンスレベルは非 常に低く結果の解釈には不確実性が伴う。

一方，2012年に報告された大腿骨近位部骨折手 術患者 18,158 症例 (患者年齢の中央值 : 80 歳超, 区 域麻酔を受けた患者は5,254症例：28.9\%)に対して 実施したサブグループ解析の結果，転子部骨折では 区域麻酔群で全身麻酔群と比較して呼吸器合併症が 有意に少なく，頸部骨折ではそのような有意差を認 めなかった ${ }^{21}$. 大腿骨近位部骨折と総称しているが, 骨折部位を詳細に分類すると麻酔法の選択が予後に 影響しうることは認識しておく必要がありそうであ る。また，術前も含めた大腿骨近位部骨折の周術期 鎮痛手段として単回投与の未梢神経ブロックの有用 性も示されている。2017年に報告されたコクラン レビューでは，単回投与の未梢神経ブロックは実施 
後 30 分で有意に痛みを減少させるほか, 肺炎の発 生率を低下させ術後の離床も促進することが示され た ${ }^{22)}$. 他の術式と異なり術前から強い痛みを伴う大 腿骨近位部骨折患者に対する区域麻酔の有用性は, 術前も含めた総合的な評価を行うことで今後新たな エビデンスが出てくる可能性がある.

\section{$\mathrm{V}$ 人工股関節置換術 / 人工膝関節置換術}

人工関節置換術の代表的な術式は人工膝関節置換 術(total knee arthroplasty : TKA) と人工股関節置 換術(total hip arthroplasty：THA)である。これら の手術適応となる患者は高齢者が多く，ハイリスク 患者も含まれやすい，他の項に含まれる術式よりも 実施される件数が多いため，ょり大規模な調査が多 いのが特徵である。2014年に，TKAおよびTHA患 者を年齢で区分し麻酔法の違いが術後経過に与える 影響を調査した大規模な研究が発表された ${ }^{23)}$ 。この 研究では, 米国の約 500 病院における THA あるい はTKA 患者約 800,000 症例を対象とし, 年齢 $(<65 \mathrm{y}$, 65-74y，75-99y) と呼吸・循環器系の基礎疾患の有 無で分類し解析を行った。全身麻酔との併用も含め て, TKA や THAの麻酔管理に脊髄幹麻酔を用い ると, 年齢や基礎疾患の有無にかかわらず, 呼吸器 合併症, 循環器合併症, ICU 管理割合, 在院日数が 有意に減少することが明らかとなった。また，脊髄 幹麻酔の全身麻酔に対する優位性は患者年齢が上昇 するほど高まることも示された。現時点では，脊髄 幹麻酔の使用が予後に好影響を与える機序は明らか ではなく，今後の検討課題である。一方で，全身麻 酔との併用を含めても春髄幹麻酔の使用頻度は約

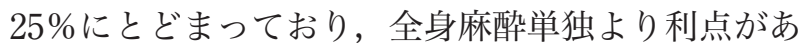
るにもかかわらずあまり実施されていない現状があ る. 脊髄幹麻酔の使用頻度が低い背景を調査し, 使 用頻度を増加させる方策を検討する必要がある。

60 歳以上でASA-PS III またはIVのハイリスク患 者に対する THAの麻酔法として「持続脊髄くも膜 下麻酔」と「超音波ガイド下腰神経叢ブロック十坐
骨神経ブロック」を比較検討した研究では，いずれ の群も良好な麻酔効果を得て周術期の心血管合併症 は生じなかったが，持続脊髄くも膜下麻酔群では血 圧低下をきたしやすいという結果を得た ${ }^{24)}$ 。「区域 麻酔と全身麻酔」の比較ではなく「区域麻酔の中で の優劣」も生じうることが示唆され，今後このよう な比較研究が増加すると予想される。

\section{VI＼cjkstart高度肥満妊婦に対する帝王切開術}

高度肥満妊婦は，閉塞性睡眠時無呼吸症候群や妊 娠高血圧腎症をはじめとする呼吸・循環器系合併症 や糖尿病などを有することが多く，帝王切開術の麻 酔管理における安全性に関する予備力が減少してい る状態にある. 2016年にアップデートされた American Society of Anesthesiologists Task Forceによる 産科麻酔診療ガイドラインでは，「大部分の帝王切 開術において全身麻酔よりも脊髄くも膜下麻酔や硬 膜外麻酔が選択されるべきである」と述べられてい る ${ }^{25)}$. 特に肥満妊婦では全身麻酔を回避するために 早めに硬膜外カテーテルあるいは脊髄くも膜下カテ ーテルを留置するべきであるとされている。このこ とから，特に肥満妊婦においては基本的に区域麻酔 法が望ましいことが示唆される。

しかしながら，高度肥満妊婦の帝王切開術に対す る麻酔管理法の優劣を調査した論文は少ない。 2017 年に肥満と帝王切開術の安全性の関係を調査した前 向き観察研究が公表された ${ }^{26)}$ 。この研究では, 妊婦 をBMIにより non-obesity $\left(\mathrm{BMI}<30 \mathrm{~kg} / \mathrm{m}^{2}\right)$, severe $\operatorname{obesity}\left(30 \mathrm{~kg} / \mathrm{m}^{2} \leqq \mathrm{BMI} \leqq 40 \mathrm{~kg} / \mathrm{m}^{2}\right)$, morbid obe$\operatorname{sity}\left(\mathrm{BMI}>40 \mathrm{~kg} / \mathrm{m}^{2}\right)$ に分類している. 解析の結果, morbid obesity群ではnon-obesity 群と比較して胎 児仮死，妊娠高血圧腎症，多胎妊娠，羊水異常の割 合が有意に高かった。また，帝王切開時の出血量も 有意に多かった。また，全身麻酔，硬膜外麻酔，硬 膜外麻酔併用春髄くも膜下麻酔に分類した麻酔法の うち，前二者は morbid obesity 群で non-obesity 群 と比較して有意に実施割合が高かった。脊髄くも膜 
下麻酔の実施状況に関しては, morbid obesity群で はnon-obesity 群と比較して穿刺回数が有意に多 く，坐位で穿刺した症例の割合も有意に高かった。 しかしながら，麻酔法の選択が予後に影響を与える というデー夕は得られておらず，いずれの麻酔法も 高度肥満妊婦に対する安全かつ効果的な手段である と結論づけられている。 上述のとおり高度肥満妊婦 の帝王切開術に対しては区域麻酔が望ましいとされ ているが，手技の難易度が高いことに留意が必要で ある。麻酔法にかかわらず高度肥満妊婦は低酸素血 症や呼吸困難をきたしやすく，これらの病態は胎児 仮死の発生と関与しうるため慎重な対応が必要とな る。

\section{おわりに}

ハイリスク患者の周術期管理において，病態や術 式ごとに区域麻酔が予後に与える影響について文献 的に考察した。区域麻酔と一括りにすることは困難 であり, 統計学的には有意差が出ている報告はある ものの個々の症例は施設の実情により一概に研究結 果を日常臨床に当てはめるのは現実的ではない。ま た，区域麻酔併用の手術中は鎮静を行うこともあり 解釈がさらに複雑になる。病態や術式ごとの最適な 麻酔法を選択するためのエビデンスに関する知識は 必要であるが, 麻酔法にかかわらず安全な周術期管 理を提供できる麻酔科医としての高い技術を身につ けることがより重要である。

\section{参考文献}

1) Rodgers A, Walker N, Schug S, et al. : Reduction of postoperative mortality and morbidity with epidural or spinal anaesthesia : results from overview of randomised trials. BMJ $321: 1493,2000$

2) Kooij FO, Schlack WS, Preckel B, et al. : Does regional analgesia for major surgery improve outcome? Focus on epidural analgesia. Anesth Analg 119 : 740-744, 2014

3) POISE Study Group, Devereaux PJ, Yang H, et al. : Effects of extended-release metoprolol succinate in pa- tients undergoing non-cardiac surgery (POISE trial) : a randomised controlled trial. Lancet $371: 1839-1847$, 2008

4) Devereaux PJ, Mrkobrada M, Sessler DI, et al. : Aspirin in patients undergoing noncardiac surgery. N Engl J Med 370 : 1494-1503, 2014

5) Leslie K, Myles P, Devereaux P, et al. : Neuraxial block, death and serious cardiovascular morbidity in the POISE trial. Br J Anaesth $111: 382-390,2013$

6) Leslie K, McIlroy D, Kasza J, et al. : Neuraxial block and postoperative epidural analgesia : effects on outcomes in the POISE-2 trial. Br J Anaesth 116:100112, 2016

7) Toghill BJ, Saratzis A, Bown MJ : Abdominal aortic aneurysm - an independent disease to atherosclerosis? Cardiovasc Pathol 27 : 71-75, 2017

8) Hertzer NR, Beven EG, Young JR, et al. : Coronary artery disease in peripheral vascular patients. A classification of 1000 coronary angiograms and results of surgical management. Ann Surg 199 : 223-233, 1984

9) Holda MK, Iwaszczuk P, Wszolek K, et al. : Coexistence and management of abdominal aortic aneurysm and coronary artery disease. Cardiol J 2018 [Epub ahead of print]

10) Matsushita K, Kwak L, Ballew SH, et al. : Chronic kidney disease measures and the risk of abdominal aortic aneurysm. Atherosclerosis $279: 107-113,2018$

11) Guay J, Kopp S : Epidural pain relief versus systemic opioid-based pain relief for abdominal aortic surgery. Cochrane Database Syst Rev 2016(1) : CD005059

12) Bardia A, Sood A, Mahmood F, et al. : Combined epidural-general anesthesia vs general anesthesia alone for elective abdominal aortic aneurysm repair. JAMA Surg 151 : 1116-1123, 2016

13) Hajibandeh S, Hajibandeh S, Adasonla K, et al. : Locoregional versus general anaesthesia for elective endovascular aneurysm repair - results of a cohort study and a meta-analysis. Vasa $47: 209-217,2018$

14) Aulivola B, Hile CN, Hamdan AD, et al. : Major lower extremity amputation : outcome of a modern series. Arch Surg 139 : 395-399 ; discussion 399, 2004

15) Moreira CC, Farber A, Kalish JA, et al. : The effect of anesthesia type on major lower extremity amputation in functionally impaired elderly patients. J Vasc Surg $63: 696-701,2016$

16) Pisansky AJB, Brovman EY, Kuo C, et al. : Perioperative outcomes after regional versus general anesthesia for above the knee amputations. Ann Vasc Surg 48 : 53-66, 2018 
17) Urwin SC, Parker MJ, Griffiths R : General versus regional anaesthesia for hip fracture surgery : a metaanalysis of randomized trials. Br J Anaesth $84: 450-$ 455, 2000

18) Parker MJ, Urwin SC, Handoll HH, et al. : General versus spinal/epidural anaesthesia for surgery for hip fractures in adults. Cochrane Database Syst Rev 2000 (4) : CD000521

19) Luger TJ, Kammerlander C, Gosch M, et al. : Neuroaxial versus general anaesthesia in geriatric patients for hip fracture surgery : does it matter? Osteoporos Int $21:$ S555-S572, 2010

20) Guay J, Parker MJ, Gajendragadkar PR, et al. : Anaesthesia for hip fracture surgery in adults. Cochrane Database Syst Rev 2 : CD000521, 2016

21) Neuman MD, Silber JH, Elkassabany NM, et al. : Comparative effectiveness of regional versus general anesthesia for hip fracture surgery in adults. Anesthesiology $117: 72-92,2012$

22) Guay J, Parker MJ, Griffiths R, et al. : Peripheral nerve blocks for hip fractures. Cochrane Database Syst Rev 5: CD001159, 2017

23) Memtsoudis SG, Rasul R, Suzuki S, et al. : Does the impact of the type of anesthesia on outcomes differ by patient age and comorbidity burden? Reg Anesth Pain Med 39 : 112-119, 2014

24) Aksoy M, Dostbil A, Ince I, et al. : Continuous spinal anaesthesia versus ultrasound-guided combined psoas compartment-sciatic nerve block for hip replacement surgery in elderly high-risk patients : a prospective randomised study. BMC Anesthesiol 14: 99, 2014

25) Practice Guidelines for Obstetric Anesthesia : An Updated Report by the American Society of Anesthesiologists Task Force on Obstetric Anesthesia and the Society for Obstetric Anesthesia and Perinatology. Anesthesiology $124: 270-300,2016$

26) An X, Zhao Y, Zhang Y, et al. : Risk assessment of morbidly obese parturient in cesarean section delivery : A prospective, cohort, single-center study. Medicine (Baltimore) $96:$ e 8265,2017

\title{
Does Regional Anesthesia Affect the Prognosis of High-risk Surgical Patients?
}

\author{
Hiroaki MURATA \\ Department of Anesthesiology, Nagasaki University School of Medicine
}

Neuraxial anesthesia had been reported to reduce postoperative mortality and serious complications. However, recent studies showed no relevant effect. The current trend is to analyze the influence of anesthesia technique on the prognosis of high-risk surgical patients using secondary data sets derived from large-scale studies. The purpose of this literature review is to introduce recent studies on whether anesthesia technique affects the prognosis of high-risk surgical patients undergoing particular surgical procedures.

Key Words : Regional anesthesia, Prognosis, High-risk surgical patients

The Journal of Japan Society for Clinical Anesthesia Vol.40 No.1, 2020 